Doi: HTTPS://DOI.ORG/10.23910/IJEP/2018.5.3.0255

\title{
A Study on the Influence of Hindu Mythological Characters on Management Practices
}

\author{
Piyush Mehta ${ }^{1 *}$, Ashok K. Thakur ${ }^{2}$, Ishaan Chauhan ${ }^{1}$ and Nikhil Uprety ${ }^{3}$
}

${ }^{1}$ Dept. of Business Management, Dr. Y.S. Parmar University of Horticulture \& Forestry, Nauni, Solan, H.P. (173 230), India

${ }^{2}$ Dr. Y.S. Parmar University of Horticulture \& Forestry, Krishi Vigyan Kendra, Rohru, Shimla, H.P. (171 207), India

${ }^{3}$ Himachal Pradesh University Business School, HPU, Shimla, H.P. (171 005), India

\section{Corresponding Author}

Piyush Mehta

e-mail: piyushabm@gmail.com

\author{
Article History \\ Article ID: IJEP0255 \\ Received in $15^{\text {th }}$ June, 2018 \\ Received in revised form 29 $9^{\text {th }}$ July, 2018 \\ Accepted in final form $17^{\text {th }}$ August, 2018
}

\begin{abstract}
Indian mythology is one of the richest elements of Indian culture, which enriches it further and makes it a unique one in the world. Interesting aspect of the stories and characters in Indian mythology is that they are usually meant to convey subtle facts, rules and maxims to guide decisions in management. The study has mainly intended to identify relevance of Hindu mythological characters in the decision making process of managers. The study has also highlighted the relationships of management styles of managers with the techniques of different Hindu mythological characters and it has even presented the perception of managers regarding the application of Hindu mythology in managing their operation. The study was mainly conducted at the selected corporate houses both private and public sector units mainly located at Shimla district of Himachal Pradesh. Most profoundly, study has observed that perceptions of managers regarding the application of Hindu mythology were enthusiastic but the lack of organizational view to bring mythological based managerial training is considered to big challenge ahead.
\end{abstract}

Keywords: Hindu mythology, management style, decision making process, managerial perception

\section{Introduction}

Indian mythology is one of the richest elements of Indian culture, which enriches it further and makes it a unique one in the world. Through generations, different stories in Indian mythology have been passed from generation to generation either by word of mouth or through carefully stored scriptures. Interesting aspect of the stories and characters in Indian mythology is that they are usually meant to convey subtle facts, rules and maxims to guide decisions in management as well as our daily lives (Bhattacharya, 2005). All beliefs are mythological as they are indifferent to rational thought - they make room for fantastic ideas like ocean of milk, flying horses, and virgin births. Every incidence teaches us a new lesson and in itself is a classic example of putting management at its best use and getting the work done (Pattanaik, 2007). There are numerous management lessons that students and corporate leaders can take from Prince Ram to succeed in the present environment of globalised economy. He alone is known as the Maryada purushottam or perfect human being. In fact, the Ramayana itself starts with a discussion between the author Valmiki and a learned sage named Narada (Muniapan, 2008). Through better understanding how these principles affect the life of Sri Ram and other great leaders, we can better see their potential in our own lives.

Knowledge is paired with honesty, courage with competence, compassion with valor, etc. The use of management principles is also very clearly visible in that of Hanuman going to Lanka. His mission was to locate Sita there and give her Prince Ram's message. When it became clear that Sita was in Lanka, Jamvant asked Hanuman to go there. He helped him in realizing his true potential and motivated him to go into the enemy's camp (Panda and Gupta, 2007). The relevant lesson from the Mahabharata is the spirit of team work which is the essence of modern management. Kauravas did not show team work. They all fought their own individual wars. They were like bees, hornets and mosquitoes put together in a jar. While the Pandavas were a one team, one goal. The Mahabharatha has many more lessons for the modern day manager like Subordination of individual interest to achieve common goal, Commitment of Team members, Assigning of the right man to the right job, Leadership as an art of inspiring team members and Analysis of Opportunities and exploiting the situation and many more (Kejriwal and Krishnan, 2004). The holy Gita is known as management epic. Its a practical psychology of transformation which offers us the tools to connect with our 
deepest intangible essence. It makes us learn to participate in the battle of life with right knowledge (Satpathy, 2008).

Management is a process of aligning people and getting them committed to work for a common goal to the maximum social benefit-in search of excellence. The critical question in all managers' minds is how to be effective in their job. The answer to this fundamental question is found in the Bhagavad-Gita Gita, which repeatedly proclaims that "you must try to manage yourself." The reason is that unless a manager reaches a level of excellence and effectiveness, he or she will be merely a face in the crowd (Parashar, 2008). The Lord of Success, the son of Shiva and Parvati, Ganesha has an elephantine countenance with a curved trunk and big ears, and a huge pot-bellied body of a human being. He is the Lord of success and destroyer of evils and obstacles. To the inspiration of managers Ganesha is symbol of wisdom, goal oriented, writer and communicator, quick thinker and problem solver (Pattanaik, 2006). Shiva (Śiva, meaning "auspicious one") is the destroyer god of the Hindu Trinity. Shiva is seen as the Supreme God. There are innumerable manifestations of Shivji. Lord Shiva is usually worshipped in the abstract form of Shiva linga. He is represented as a handsome young man immersed in deep meditation or dancing the Tandava in his manifestation of Nataraja, the Lord of the dance, goodness, humility, and every good quality a human should have (Tapasyananda, 1991).

Lord Krishna is an instigator of all forms of knowledge and born to establish the religion of love. He came as the messenger of peace (Satpathy and Muniapan, 2008). According to Sri Rama the intellectual elites are to be appointed in the prime posts, which require decision making and planning. According to Sri Rama for attending peace and prosperity everyone has to be assigned with a work as per their ability and worth or else it would lead to chaos in the organisation (Gregor, 1960). For increasing managerial effectiveness which can be divided into interpersonal roles, informational roles and decisional roles. Interpersonal roles include the roles of managers such as figurehead, leader and liaison roles, which arises from a manager's status and authority in an organization (Minzberg, 1973). The prospect of exploring Valmiki Ramayana in other areas of management such as strategic management, people management, and others can be considered in the near future (Muniapan and Satpathy, 2010). Managerial effectiveness is subjective and generic area to explore, however in this paper the principles of managerial effectiveness which relates to work motivation (Panda and Gupta, 2007).

Since, Hindus believe there is one God (with a capital G), there are 330 million gods for every caste, profession, village and even for your specific household. There are gods in minerals, trees, animals and books. Understanding this complex web is key to understanding and decoding our beliefs, values and behavior. As the purpose of the organization is to help the employee create wealth, learn new skills and be empowered. In the absence of any one of the three, the relationship between the employer and employee will not be a vibrant one (Pattanaik, 2011). Effectiveness involves doing the right things, in the right way and effectiveness translates a manager's intelligence and knowledge into results. Effectiveness ultimately makes a manager successful in achieving organisational goals. Although there have been several models, methods and views on managerial effectiveness presented in the western management literature; there seems to be no universal or standard approach towards developing managerial effectiveness which can be applied to every country and community (Samson and Daft, 2009).

\section{Materials and Methods}

The descriptive research design was adopted for the concerned research study. A sample size of 120 (corporate entities) respondents (mangers, employees etc.) were taken for the research study at Shimla district of Himachal Pradesh. Convenience sampling technique was used for the present study for collection of data. The study was conducted by using both Primary and Secondary data. The primary data for the present study was collected with the help of questionnaire. The secondary data for the present study was collected from journals, magazines, research articles, newspapers, and website. Simple mathematical and statistical tools, including Arithmetic mean, standard deviation and Total Weightage Score method were used for satisfying the objectives with a view of keeping the analysis simple and easy to understand. The arithmetic mean has been applied to study the opinion of the sample respondents on 5-point scale for different statements (Kothari, 2004). Total weighatge score method in which we have to provide different Weights according to their importance and multiply the values of the items $(X)$ by the weights $(\mathrm{W})$ as provided. Then add all the values to obtain the total weights of all the items and the one which get highest score will get the first rank and the one which get the lowest score will get the lowest rank (Kumar, 2014). Chi- square describes the magnitude of discrepancy between the theory and observation (Kumar, 2008). The concerned research paper was initiated with the key objectives to identify the relevance of Hindu mythological characters in the decision making process of managers. The study has also highlighted the relationships of management styles of managers with the techniques of different Hindu mythological characters and it has even presented the perception of managers regarding the application of Hindu mythology in managing their operations.

\section{Results and Discussion}

\subsection{Age status of the respondents}

It was observed that respondents in the range of 25-30 yrs of age were the maximum, i.e. (57\%) followed by the category of 31-36 yrs of age. Thus, it may have been stated that largely young managers were quite inclined to share information regarding the influence of mythological characters at their working place (Table 1). 


\begin{tabular}{lcc}
\hline \multicolumn{2}{l}{ Table 1: Age status of the respondents } \\
\hline Age status (years) & \multicolumn{2}{c}{ Respondents } \\
\cline { 2 - 3 } & Number & (\%) \\
\hline $18-24$ & 5 & 7 \\
$25-30$ & 38 & 57 \\
$31-36$ & 17 & 25 \\
Above 36 & 7 & 10 \\
Total & 67 & 100 \\
\hline
\end{tabular}

Field Survey, 2017

\subsection{Gender status of the respondents}

It was indicated that respondents were maximum male, i.e (74\%) and about (26\%) were females, thus this can be stated that, males were more inclined to share information regarding their perception and influence of the mythological charecters at their their work place (Table 2).

\begin{tabular}{lcc}
\hline \multicolumn{2}{l}{ Table 2: Gender status of the respondents } \\
\hline \multirow{2}{*}{ Gender status } & \multicolumn{2}{c}{ Respondents } \\
\cline { 2 - 3 } & Number & $(\%)$ \\
\hline Male & 50 & 74 \\
Female & 17 & 26 \\
Total & 67 & 100 \\
\hline
\end{tabular}

Field Survey, 2017

\subsection{Positional status of the respondents}

It is noted that positional status of most of the respondents were that of middle management i.e about (75\%) followed by low management i.e (18\%) and lastly the top management which were merely (7\%). Thus it may be stated that middle management people were more inclined to share their perceptions regarding influence of the Hindu mythological charecters at their their work place (Table 3).

\begin{tabular}{lcc}
\hline \multicolumn{2}{l}{ Table 3: Positional status of the respondents } \\
\hline Positional status & \multicolumn{2}{c}{ Respondents } \\
\cline { 2 - 3 } & Number & $(\%)$ \\
\hline Top management & 5 & 7 \\
Middle management & 50 & 75 \\
Low management & 12 & 18 \\
Total & 67 & 100 \\
\hline
\end{tabular}

Field survey, 2017

\subsection{Monthly income of the respondents}

It was indicated that monthly income of most of the respondents i.e (42\%), were in the range of ₹ $21,000-30,000$ followed by the income that ranges between $31,000-40,000$ i.e (25\%), almost same goes the case for income ranging above
40,000 , which was nearly (21\%). However respondents falling in the range of monthly income of less than or equal to ₹ $20,000$ were only (12\%) (Table 4$)$.

\begin{tabular}{lcc}
\hline \multicolumn{2}{l}{ Table 4: Monthly income of the respondents } \\
\hline Income & \multicolumn{2}{c}{ Respondents } \\
\cline { 2 - 3 }$\left(\right.$ ₹ month $\left.^{-1}\right)$ & Number & Percentage (\%) \\
\hline 20,000 or less & 8 & 12 \\
$21,000-30,000$ & 28 & 42 \\
$31,000-40,000$ & 17 & 25 \\
above 40,000 & 14 & 21 \\
Total & 67 & 100 \\
\hline
\end{tabular}

Field Survey, 2017

\subsection{Educational qualification of the respondents}

In reference to the educational qualification, most of the respondents is post graduation i.e. (52\%), followed by professionals i.e. (25\%) and then graduates and diploma holders (14\%) and (9\%) respectively.Thus it can be stated that most of the managers are post graduates and are more inclined towards sharing their views regarding influence of the Hindu mythological charecters at their their work place (Table 5).

\begin{tabular}{lcc}
\hline \multicolumn{2}{l}{ Table 5: Educational qualification of the respondents } \\
\hline Educational quali- & \multicolumn{2}{c}{ Respondents } \\
\cline { 2 - 3 } fication status & Number & Percentage (\%) \\
\hline Graduation & 13 & 14 \\
Post graduation & 48 & 52 \\
Professional & 23 & 25 \\
Diploma & 7 & 9 \\
Total & 91 & 100
\end{tabular}

Field Survey, 2017

\subsection{Experience status of the respondents}

It was observed that experience of maximun number of respondents lies between (0-5)years i.e. (46\%) followed by respondents with experience of above 15 years.i.e.(30\%).Thus it can be stated that maximum number of respondents that were inclined to share their experince were either freshers with $0-5$ years of experience or managers with an experience of 15 years of above (Table 6).

\subsection{Most idealised Hindu mythological character at workplace}

It was inferred that Lakshmi,Saraswati,Krishna and Ganesha were among the dieties who were most idealised by the respondents at their work place.The percentage of respondents being (16\%, 16\%, $12 \%$ and $14 \%$ respectively). This was followed by other dieties such as Rama, Krishna, Shiva, Durga and Hanuman with percentage of $(9 \%, 12 \%, 8 \%$, 


\begin{tabular}{lcc}
\hline \multicolumn{2}{l}{ Table 6: Experience status of the respondents } \\
\hline Experience (years) & \multicolumn{2}{c}{ Respondents } \\
\cline { 2 - 3 } & Number & Percentage (\%) \\
\hline $0-5$ & 31 & 46 \\
$5-10$ & 8 & 12 \\
$10-15$ & 8 & 12 \\
Above 15 & 20 & 30 \\
Total & 67 & 100 \\
\hline
\end{tabular}

Field Survey, 2017

$5 \%$ and $5 \%$ respectively). Many of the respondents also stated that they idealised each of the mentioned dieties (Table 7).

Table 7: Most idealised Hindu mythological character at workplace

\begin{tabular}{lcc}
\hline Characters idealized & \multicolumn{2}{c}{ Respondents } \\
\hline Ganesha & Number & Percentage (\%) \\
Rama & 17 & 14 \\
Krishna & 15 & 9 \\
Hanuman & 6 & 12 \\
Shiva & 10 & 5 \\
Durga & 6 & 8 \\
Lakshmi & 20 & 5 \\
Saraswati & 20 & 16 \\
All & 18 & 16 \\
Total & 123 & 15 \\
\hline
\end{tabular}

Field survey, 2017

\subsection{Source of information to learn attributes of ideal Hindu mythological characters}

It was eveidently noted that substantuially respondents (41\%) mentioned that the source of inspiration regarding gaining attributes of their ideal Hindu mythological charactershad been mass media (TV or print), about (34\%) of respondents stated that for them the source had been friends, relatives, parents and collegues. About (16\%) of the repondents mentioned that source of information for them had been mythological specialists and about (9\%) of the respondents were of opinion that Internet or mobile had been source of information for them. From this it can be inferred that mass media proved to be greatest source of information for the respondents and at the same time contribution made by parents, friends and relatives as a source of information was also considerable (Table 8).

3.9. Frequency to seek inspiration (Through worships or reading or listening) from Hindu mythological characters

It was observed that frequency to seek inspiration through
Table 8: Source of information to learn attributes of ideal Hindu mythological characters

\begin{tabular}{lcc}
\hline Source of information & \multicolumn{2}{c}{ Respondents } \\
\cline { 2 - 3 } & Number & Percentage (\%) \\
\hline $\begin{array}{l}\text { Friends, relatives, parents \& } \\
\text { colleagues }\end{array}$ & 54 & 34 \\
Internet or mobile & 14 & 9 \\
Mythological specialists or & 25 & 16 \\
others & & \\
TV or Print & 66 & 41 \\
Total & 159 & 100 \\
\hline
\end{tabular}

Field Survey, 2017

Hindu mythological characters was stated as seldom by maximum of the respondents i.e. about (52\%), about (34\%) of the respondents stated that they tend to seek insipration frequently and very less i.e. (14\%) stated to seek inspiration daily (Table 9).

Table 9: Frequency to seek inspiration (Through worships or reading or listening) from Hindu mythological characters

\begin{tabular}{lcc}
\hline Source of information & \multicolumn{2}{c}{ Respondents } \\
\cline { 2 - 3 } & Number & Percentage (\%) \\
\hline Daily & 9 & 14 \\
Frequently & 22 & 34 \\
Seldom & 33 & 52 \\
Total & 64 & 100 \\
\hline
\end{tabular}

Field survey, 2017

\subsection{Tendency of inspiration received from various} mythological characters at work place

Largely the mythological characters tends to provide common amount of inspiration but as far as inspiration in workplace is concerned (Table10) illustrates a detail framework of tendency of respondents over largest kind of inspiration received in reference to different characters. It is observed that Durga is highest source of inspiration for courage. Building confidence has been observed to be observed to be inspired from Lord Ganesha. Composure inspired from Lord Rama. Positivity has been generated with inspiration of Lord Rama again. Similarly emphathaticness with the organizational work form have been inspired through most profound mythological character namely Lord Rama. However rationality has been seemed to inspire from Lord Krishna. Intellectuality has been inspired through Goddess Saraswati. Discipline have been derived from Lord Rama, similarly truthfulness has also been inspired from Lord Rama again. Lastly kind fullness has been richly inspired from Lord Ganesha. It's clearly evident from the given analytical table that Lord Rama has been the source 


\begin{tabular}{lcccccccc}
\hline \multicolumn{7}{l}{ Table 10: Tendency of Inspiration received from various mythological characters at work place } \\
\hline Characters or Inspiration received & Ganesha & Rama & Krishna & Hanuman & Shiva & Durga & Lakshmi & Saraswati \\
\hline Courage & $9(13)^{*}$ & $10(14)$ & $6(8)$ & $16(23)$ & $15(21)$ & $11(15)$ & $0(0)$ & $4(6)$ \\
Confidence & $14(19)$ & $13(18)$ & $10(14)$ & $15(20)$ & $6(8)$ & $2(3)$ & $4(5)$ & $10(14)$ \\
Composure & $7(10)$ & $17(25)$ & $14(20)$ & $7(10)$ & $4(6)$ & $2(3)$ & $9(13)$ & $9(13)$ \\
Positivity & $7(10)$ & $12(18)$ & $8(12)$ & $10(15)$ & $3(4)$ & $5(7)$ & $11(16)$ & $11(16)$ \\
Empathetic & $6(10)$ & $14(23)$ & $8(13)$ & $7(12)$ & $9(15)$ & $7(12)$ & $4(7)$ & $5(8)$ \\
Rational & $9(19)$ & $2(4)$ & $18(38)$ & $11(23)$ & $4(8)$ & $2(4)$ & $1(2)$ & $1(2)$ \\
Intellectual & $9(12)$ & $9(12)$ & $11(15)$ & $4(5)$ & $7(9)$ & $4(5)$ & $12(16)$ & $19(25)$ \\
Discipline & $5(6)$ & $28(35)$ & $8(10)$ & $8(10)$ & $12(15)$ & $6(7)$ & $4(5)$ & $10(12)$ \\
Truthfulness & $14(16)$ & $40(47)$ & $0(0)$ & $10(5)$ & $5(6)$ & $4(5)$ & $2(2)$ & $10(12)$ \\
Kind fullness & $22(26)^{\#}$ & $15(18)$ & $2(2)$ & $10(12)$ & $5(6)$ & $8(9)$ & $11(13)$ & $12(14)$ \\
\hline
\end{tabular}

*: No. of Respondents (Per cent of Response for each character); \#: Highest \% age of Respondents (Bold), for each character; Field Survey, 2017

inspiration for most of the good traits one tends to desire at the workplace for the better working results.

3.11. Relationship of mythological characters with the tendency to receive distinctive kind of inspiration by the respondents at the work place

As the calculated value of Chi-square is 39.1, whereas, the tabulated value at the degree of freedom $((\mathrm{u}-\mathrm{i})(\mathrm{v}-1))$ i.e. 14 at the significance level of $(5 \%)$ is 23.8 . Hence, the calculated value is more than the tabulated value. Thereby, it may have been stated that the Ho (Null hypothesis) is rejected and it is

Table 11: Relationship of mythological characters with the tendency to receive distinctive kind of inspiration by the respondents at the work place

\begin{tabular}{lcccc}
\hline C/NR & CCC & PER & IDEK & Total \\
\hline Ganesha & 30 & 22 & 50 & 102 \\
Rama & 40 & 28 & 92 & 160 \\
Krishna & 30 & 34 & 21 & 85 \\
Hanuman & 38 & 28 & 32 & 98 \\
Shiva & 25 & 16 & 29 & 70 \\
Durga & 15 & 14 & 22 & 51 \\
Lakshmi & 13 & 16 & 29 & 58 \\
Saraswati & 23 & 17 & 51 & 91 \\
Total & 214 & 175 & 326 & 522 \\
\hline
\end{tabular}

C/NR: Characters/Inspiration received; CCC: Courage; Confidence; Composure; PER: Positivity; Empathetic; Rational; IDTK: Intellectual; Discipline; Truthfulness; Kindfulness

stated that there is a significant relationship of mythological characters with the tendency to receive a distinctive kind of inspiration by the respondents at the work place (Table 11).

3.12. Appropriate opinion of respondents in reference to inspiration received from different Hindu mythological characters over different stages of decision making

In order to understand the opinion of respondents in reference to inspiration received from different Hindu mythological characters over different stages of decision making, The Chi square test was applied, analyzing that as the calculated value of Chi-square is 13.87 , whereas, the tabulated value at the degree of freedom ((u-i) (v-1)) i.e. 14 at the significance level of $(5 \%)$ is 12.59 . Hence, the calculated value is more than the tabulated value. Thereby, it may have been stated that the Ho (Null hypothesis) is rejected and it is stated that there is a significant relationship of mythological characters with opinion of respondents in reference to inspiration received over different stages of decision making (Table 12).

Table 12: Appropriate opinion of respondents in reference to inspiration received from different Hindu mythological characters over different stages of decision making

\begin{tabular}{lcccc}
\hline $\begin{array}{l}\text { Inspiration received/Char- } \\
\text { acters }\end{array}$ & ES & POC & EICA & Total \\
\hline Ganesha and Rama & 20 & 40 & 26 & 86 \\
Krishna and Durga & 7 & 36 & 25 & 68 \\
Lakshmi and Saraswati & 5 & 17 & 21 & 43 \\
Hanuman and Shiva & 11 & 13 & 23 & 47 \\
Total & 43 & 106 & 95 & 244 \\
\hline
\end{tabular}

ES: Environmental scanning; POC: Planning; Organizing and coordinating; EICA: Execution and Implementation; Control and appraisal

3.13. Appropriate source of knowledge for the respondents from given Hindu mythological characters for different managerial styles

In reference to understand the appropriate source of knowledge for the respondents from given Hindu mythological 
characters for different managerial styles, it was analyzed with the help of Chi-square test, resulting that the calculated value of Chi-square is 19.00 . Whereas, the tabulated value at the degree of freedom ( $(u-i)(v-1))$ i.e. 12 at the significance level of $(5 \%)$ is 21.02 . Hence, the calculated value is less than the
Tabulated value. Thereby, it may have been stated that the Ho (Null hypothesis) is accepted and it is stated that there is no significant relationship of Mythological Characters with different managerial styles (Table 13).

Table 13: Appropriate source of knowledge for the respondents from given Hindu mythological characters for different managerial styles

\begin{tabular}{lcccccc}
\hline $\begin{array}{l}\text { Management styles or } \\
\text { characters }\end{array}$ & Contingency & Behavioral & Social & Interpersonal & Scientific & Total \\
\hline Ganesha and Rama & 12 & 17 & 32 & 18 & 5 & 84 \\
Krishna and Hanuman & 9 & 19 & 15 & 51 & 69 & 5 \\
Shiva and Durga & 9 & 13 & 8 & 8 & 8 \\
Lakshmi and Saraswati & 6 & 56 & 60 & 53 & 23 \\
Total & 36 & & & 228 \\
\hline
\end{tabular}

Field survey, 2017

3.14. Tendency of relating the appropriateness of given Hindu mythological characters to different themes

While analyzing the Tendency of relating the appropriateness of given Hindu mythological characters to different themes, it was resulted that as the calculated value of Chi-square is 157.99 , whereas, the tabulated value at the degree of freedom $((u-i)(v-1))$ i.e. 12 at the significance level of $(5 \%)$ is 21.02 . Hence, the calculated value is more than the Tabulated value. Thereby, it may have been stated that the Ho (Null hypothesis) is rejected and it is stated that there is a significant relationship of mythological characters with different themes (Table 14).

Table 14: Tendency of relating the appropriateness of given Hindu mythological characters to different themes

\begin{tabular}{lcccccc}
\hline $\begin{array}{l}\text { Themes or } \\
\text { Characters }\end{array}$ & Time & $\begin{array}{c}\text { Stra- } \\
\text { tegic }\end{array}$ & Wealth & $\begin{array}{c}\text { Knowl- } \\
\text { edge }\end{array}$ & $\begin{array}{c}\text { Eth- } \\
\text { ics }\end{array}$ & $\begin{array}{c}\text { To- } \\
\text { tal }\end{array}$ \\
\hline $\begin{array}{l}\text { Ganesha } \\
\text { and Rama }\end{array}$ & 17 & 19 & 6 & 23 & 57 & 122 \\
$\begin{array}{l}\text { Krishna and } \\
\text { Hanuman }\end{array}$ & 18 & 38 & 8 & 30 & 36 & 130 \\
$\begin{array}{l}\text { Shiva and } \\
\text { Durga }\end{array}$ & 10 & 6 & 6 & 37 & 35 & 94 \\
$\begin{array}{l}\text { Lakshmi and } \\
\text { Saraswati }\end{array}$ & 6 & 5 & 65 & 90 & 44 & 210 \\
\begin{tabular}{l} 
Total \\
\hline
\end{tabular} & 51 & 68 & 85 & 180 & 172 & 556 \\
\hline
\end{tabular}

Field survey, 2017

3.15. Perceptions of respondents regarding application of mythological teachings of their ideal Hindu mythological characters in managing their work culture

While analyzing the Perceptions of respondents regarding application of mythological teachings of their ideal Hindu mythological characters in managing their work culture, Total
Weightage score method was applied (Table 15), resulted that clarity of communication, equity and balance, commitment

Table 15: Perceptions of respondents regarding application of mythological teachings of their ideal Hindu mythological characters in managing their work culture

\begin{tabular}{|c|c|c|c|c|c|c|c|}
\hline Weightage & 2 & 1 & 0 & -1 & -2 & \multirow[t]{2}{*}{ TWS } & \multirow[t]{2}{*}{$\mathrm{R}$} \\
\hline $\mathrm{P} / \mathrm{T}$ & VHP & HP & MP & RP & NAA & & \\
\hline $\begin{array}{l}\text { Empathetic } \\
\text { and sympathy }\end{array}$ & 3 & 5 & 31 & 22 & 4 & $\begin{array}{l}6+5+0- \\
22-8=-19\end{array}$ & 8 \\
\hline $\begin{array}{l}\text { Equity and } \\
\text { balance }\end{array}$ & 2 & 14 & 41 & 5 & 0 & $\begin{array}{l}6+70+0- \\
5+0=71\end{array}$ & 2 \\
\hline $\begin{array}{l}\text { Clarity of com- } \\
\text { munication }\end{array}$ & 18 & 38 & 9 & 2 & 0 & $\begin{array}{l}36+38+0- \\
2-0=72\end{array}$ & 1 \\
\hline $\begin{array}{l}\text { Culture and } \\
\text { ethical code } \\
\text { of conduct }\end{array}$ & 4 & 3 & 35 & 10 & 2 & $\begin{array}{l}8+3+0- \\
10-2=-3\end{array}$ & 7 \\
\hline $\begin{array}{l}\text { Commitment } \\
\text { and persever- } \\
\text { ance }\end{array}$ & 18 & 27 & 16 & 5 & 0 & $\begin{array}{l}36+27+0- \\
5+0=58\end{array}$ & 3 \\
\hline $\begin{array}{l}\text { Team building } \\
\& \text { group dy- } \\
\text { namics }\end{array}$ & 4 & 19 & 34 & 8 & 0 & $\begin{array}{l}8+19+0- \\
8+0=19\end{array}$ & 6 \\
\hline $\begin{array}{l}\text { Recognition } \\
\text { and respect }\end{array}$ & 2 & 21 & 32 & 7 & 0 & $\begin{array}{l}4+21+0- \\
7+0=18\end{array}$ & 8 \\
\hline Enthusiasm & 9 & 36 & 18 & 2 & 2 & $\begin{array}{l}18+36+0- \\
2-4=48\end{array}$ & 4 \\
\hline $\begin{array}{l}\text { Character and } \\
\text { Truthfulness }\end{array}$ & 5 & 19 & 30 & 9 & 0 & $\begin{array}{l}10+19+0- \\
9+0=20\end{array}$ & 5 \\
\hline
\end{tabular}

$\mathrm{P} / \mathrm{T}$ : Perceptions/ Teachings; VHP: Very highly perceived; HP: Highly perceived; MP: Moderately perceived; RP: Rarely perceived; NAA: Not at all; TWS: Total Weightage Score; R: Rank 
and perseverance had been found to be amongst the most important features required in managing work culture as they hold ranks 1,2 and 3 respectively. Though team building, enthusiasm, recognition and respect, character and truthfulness had also been found to be quiet important as they are next in the ranking with ranks 4, 5, 6 and 7. As far as the perception of respondents is concerned, empathy and sympathy, equity and balance had been moderately perceived. In reference to clarity of communication, commitment and perseverance it had been felt to highly perceived by the respondents. Enthusiasm is also among the attribute that had been highly perceived by the respondents. In reference to team building \& group dynamics, recognition and respect, character \& truthfulness it had been felt to be moderately perceived by the respondents.

\section{Conclusion}

Study has represented a comprehensive need of clarity of communication, equity and balance, commitment and perseverance in the organization, which can be learnt and inspired from various Hindu mythological characters as idealized by respective employees working at different positional levels. As various desired traits for becoming a good corporate employee were learnt and inspirations were drawn, like courage and valour was observed from Goddess Durga, confidence \& amp; kindness inculcated from Lord Ganesha and organizational discipline and truthfulness were observed to be inspired and inculcated from Lord Rama.

\section{References}

Bhattacharya, P., 2001. Management of power: lessons from the Ramayana. Leadership and Power Ethical Explorations. Oxford University Press, New Delhi, 415-28.

Chakraborty, S.K., 1995. Wisdom leadership: leading self by the Self. Journal of HumanValues 1, 205-220.

Chakraborty, S.K., Chakraborty, D., 2008. Spirituality in Management: means or end. Oxford University Press: Delhi.

Gregor, M.D., 1960. The human side of enterprise. McGrawHill: New York, 156.

Kejriwal, A., Krishnan, V.R., 2004. The impact of vedic world view and gunas on transformational leadership.Vikalpa 29(1), 29-40.

Kothari, C.R., 2009. Research methodology: methods and techniques. New Age International Publisher, New Delhi, 15-40.

Kumar, R., 2014. Research methodology. British Library Publications, New Delhi, India, 37-45.

Kumar, R.C., 2008. Research Methodology. APH Publishing Corporation, New Delhi, India, 23-29.

Minzberg, H., 1973. The nature of managerial work. New York: Harper \& Row.

Muniapan, B., Satpathy, B., 2010. Ancient Indian wisdom for managers: the relevance of Valmiki Ramayanain developing managerial effectiveness. International Journal of Indian Culture and Business Management 3(6), 645-668.

Muniapan, B., 2006. Can the Bhagavad-Gita be used as a manual for management development of Indian managers worldwide: $5^{\text {th }}$ Asia Academy of Management Conference. Asian Management: convergence and divergence. Japan, 19-21.

Muniapan, B., 2007. Transformational leadership style demonstrated by Sri Rama in Valmiki Ramayana. International Journal of Culture and Business Management 1(1), 104-115.

Narang, S.P., 1995. Influence of the Mahabharata on kalidasa. Nag publisher: New Delhi, 258-265.

Panda, A., Gupta, R.K., 2007. Call for developing indigenous organisational theories in India: setting agenda for future. International Journal of Indian Culture and Business Management 1, 205-243.

Parashar, S.P., 2008. Winning over equals: insights from Bhagwad Geeta (Krishna-Arjuna framework). International Journal of Indian Culture and Business Management 1(3), 354-359.

Pattanaik, D., 2006. Myth=mithya: a handbook of hindu mythology. Penguin: New Delhi, 227.

Pattanaik, D., 2010. Jaya-An illustrated retelling of the Mahabharata. Penguin:New Delhi, 105-112.

Roka, P., 2006. Bhagavad Gita on effective leadership: timeless wisdom for leaders. iUniverse, 188.

Satpathy, B., Muniapan, B., 2008. The knowledge of self from the Bhagavad-Gita and its significance for human capital development. Asian Social Science 4(10), 143-150.

Tapasyananda, S., 1991. Sundara Kandam of Srimad Valmiki Ramayana. India: Madras Sri Ramakrishna Math 243-252. 